\title{
Teaching and assessment practices for academic writing: an analysis of teacher profiles
}

\section{Dyanne Escorcia}

Université de Poitiers, France

\section{Mayilin Moreno}

Universidad del Norte, Colombia

\section{Abstract}

The present research study aimed to determine what teachers do to promote the learning of academic writing. In particular, we studied how teachers teach and assess writing in higher education based on their self-reported teaching practices. We asked 64 teachers working in a Colombian university to fill in a questionnaire that we constructed for the purposes of the present study. The participants were teachers in the field of Health Sciences, the majority of whom were female $(58 \%)$, with a mean age of 44 years. Data analysis consisted of cluster analysis based on items relative to teaching and assessing academic writing in order to determine teacher profiles. A Kruskal-Wallis $\mathrm{H}$-test was then conducted to distinguish the found profiles as a function of teacher age. The results revealed three significantly different profiles: transmitting, assessing and no-adherence profiles. These profiles also varied as a function of age. These results will be discussed, taking into account a generational effect hypothesis, with regard to the tendency/lack of tendency for teachers to stimulate the learning of different components of academic writing (norms, methods and reflexive practices).

Keywords: academic writing; university teacher profiles; teaching practices; assessing practices; self-reported teacher practices.

\section{Introduction}


Writing is a key activity in higher education. It seems inherent to all disciplines, since university students use writing to assimilate the concepts and notions of their particular disciplinary field (Delcambre et al., 2012). However, the practices of academic writing vary in function by discipline areas. Castello and Mateos (2015) found that the approaches to teaching writing self-reported by teachers in Social Sciences, Law and Health Sciences gave more importance to discursive norms and the writing processes than the practices described by Engineering or Architecture teachers.

Adopting a cognitive perspective, Bereiter (1980) emphasised the contribution of writing to knowledge construction. More than just a product of learning or a mechanical act serving to collect information, writing is a form of learning through which students can structure and build knowledge. Writing is a very demanding cognitive activity (Kellogg and Raulerson, 2007) in that individuals can plan their content and think about what is to be written, how it is to be written and for what purpose. They can also review what they have written, correcting or changing the content as many times as necessary without the recipient being aware of this process of elaboration (Hayes, 2012).

Writing would thus appear to be key to the mission of universities to contribute to the social and economic performance of countries by producing knowledge and promoting lifelong learning (Organisation for Economic Cooperation and Development, 1996). In this sense, teachers play a pivotal role, as it mainly falls to them to teach students how to write. This is a particularly complex task, as it involves encouraging students to develop the intellectual abilities of planning, correcting and constructing written language so that they can build new knowledge in their disciplinary field (Reuter, 1996). In other words, teachers must teach their students the epistemic value of writing.

The present research considers that teacher practices to promote this essential component of learning in higher education constitute an illustration of the social dimension of academic writing. According to Lea and Street (1998), the interactions between writing and social practices, such as the institutional and cultural norms in learning contexts, could cause contradictions that students have to face at different stages of their progression in higher 
education. The present study will explore some characteristics of teaching practices, considering them as part of the learning context of academic writing.

\section{Studying self-reported teaching practices related to writing in higher education}

Teaching practices in higher education have been studied in the literature (Eley, 2006; Le Huu Nghia, 2017), emphasising teacher beliefs, teaching approaches and the relationship between these variables and student learning. We chose the term teaching approaches in order to study the teaching and assessment of academic writing practices in higher education. Eley (2006) insisted on the necessity of considering this term separately from that of teacher conceptions, given that the former is somewhat related to what teachers say about their teaching practices. In contrast, studies of teaching approaches in higher education have, above all, highlighted teacher-reported teaching practices (Eley, 2006).

Previous studies have identified categories of teaching approaches, and their findings have been highly consistent given that two supra-categories are in evidence (Gow and Kember, 1993; Trigwell and Prosser, 1996). In one category, some teachers view teaching as a transmission process where teachers play a key role in communicating knowledge that students then have to learn. In the other category, teaching is considered to be a process in which the students play the central role by participating in their own knowledge construction. Between these two typologies exist various other categories that differ in their degree of emphasis on either a teacher-focused or a student-focused approach.

In relation to teaching writing in higher education, Graham et al. (2002) observed three approaches: a focus on good writing; on explicit and direct instruction; or on ecological learning. In the first category, teachers tended to emphasise the correction of their students' written material with regard to linguistic norms. In the second case, it was important to the teachers to develop and train the cognitive skills of students. The final approach to teaching writing focused on the interactive and social dimensions of learning, which allowed students to learn through cooperation between pairs. However, these studies in the domain of teaching 
writing have concentrated on educational practices in primary and secondary education. Fewer studies have explored teacher self-reported approaches in higher education.

Studying the implicit beliefs of students and teachers about writing in higher education, Lea and Street (1998) observed three categories, some of which were similar to the teaching of writing practices distinguished by Graham et al. (2002). The first category emphasised language skills; the second described the social learning of discursive norms that constitute academic culture; and the third category was concerned not only with how students and teachers integrated institutional norms and practices but also the power relationships that impacted a writer's academic practices. Escorcia, et al. (2014) found that Colombian and French teachers implemented various pedagogic means, such as teaching writing methods, recalling the importance of respecting linguistic rules, or the display of reflective thinking. However, the most common self-reported practices have been related to communicating disciplinary norms for constructing academic texts.

\section{Teaching and assessing writing in higher education: educational practices in Colombia}

Grijalva (1999) and López (2010) observed that higher education institutions in Colombia exhibited a distinct lack of interest in improving their teaching practices. For many decades, the development of reading and writing skills have been restricted to those taught in Spanish language courses focusing on linguistics, grammar and pragmatics (González and Vega, 2010). This is partly the consequence of a lack of teacher training based on contextualised research with regard to the problems in schools and universities (Carlino, 2005). However, some changes in recent years have helped to focus conceptions of writing on the specific characteristics of each genre, and the role of the writer in constructing writing and knowledge (Arévalo et al., 2008).

Owing to the lack of interest reported by Grijalva (1999) and López (2010), few Columbian universities have set up systematic programmes to help students learn to write, considering it to be the job of elementary and secondary schools. Pérez et al. (2010) showed that Colombian university teachers focused on the discursive and functional dimensions of writing 
and emphasised the importance of writing as a pleasurable activity. However, this study revealed few clues as to how the practice of writing contributes to learning and the development of thinking skills, and how these processes can be efficiently assessed. According to González and Vega (2010), the traditional view that the teaching of writing should be restricted to Spanish courses still prevails in Colombian universities. These authors found that although teachers believe it is important to develop writing skills at university, they do not see this as being an essential role of university teachers.

Other research that described Colombian teacher practices for teaching and assessment of writing has confirmed that teachers do not consider ways to help students construct their texts in their courses (Vargas, 2007; Escorcia, 2015; Escorcia et al., 2014). Teachers concentrate on assessing students' final written productions and do not provide any feedback during the intermediate phases of writing. Writing is regarded merely as a product that learners generate in response to teacher orders (Escorcia, 2012). Escorcia (2015) found that Colombian university teachers in the Psychology domain concentrated on communicating disciplinary norms for academic texts (APA reference style, expected text structure, etc.) and upholding the linguistic standards of the Spanish language, clearly viewing writing solely as a product. Consistent with this result, Cadena et al. (2007) observed that writing is also viewed as a product—and not a process—in the fields of Economics and Engineering.

\section{Research questions}

Considering that writing plays an essential role for learning in higher education, and that this activity presents challenges to university teachers in terms of their educational practices, the objective of the present study was to discover the extent to which teachers actually implement actions to facilitate their students to achieve mastery of diverse facets of academic writing, especially the reflective dimension of writing. In particular, we looked at how teachers teach and assess writing in higher education. We analysed teaching practices via the advice teachers said they gave to their students when setting a written assignment, and their assessment practices via the criteria they declare to use when they judge these written products. Based on these analyses, we sought to typify the teaching and assessment of 
academic writing practices by identifying teacher profiles and interactions with individuals based on teacher age. Studying the case of Colombian university teachers, in particular, could contribute to knowledge as to how education practices progress in a context where the question of teaching academic writing does not seem particularly integrated.

\section{Methods}

\section{Context of the study}

This study was developed in a private university on the Colombian Caribbean coast. This university was founded 45 years ago and currently has 4,321 students. It offers 11 academic programmes in the field of Health: Bacteriology, Nursing, Medicine, Physiotherapy, Psychology, Social Work, Optometry, Nutrition and Dietetics, Dentistry and Occupational Therapy. The pedagogy model prescribed by this university is centred on a dialogical model which points to the complexity of the human being and to the importance of social interaction in the construction of knowledge.

\section{Participants}

Our sample comprised 64 teachers. Table 1 shows the characteristics of the sample. Participants were mainly female (58\%) and their mean age was 44 years (range: $26-70$ years). The participants were mainly novice and moderately experienced university teachers with between $1-10$ years of experience ( $81 \%$ of the sample). The most experienced participants (five teachers) had 28-38 years of teaching in higher education.

The majority of our participants (59\%) taught students in a specific year of study: third year $(17 \%)$, fifth year $(16 \%)$, second year $(12 \%)$, first year $(8 \%)$ or fourth year $(6 \%)$. The remainder (41\%) taught students from several different years. In other words, our participants were mainly teachers in a specific year of study, and most taught in the upper levels of study.

\section{Table 1. Sample characteristics.}

\begin{tabular}{lc}
\hline Variables & $n(\%)$ \\
\hline Age (years) & $26-70$ \\
Range & $44.26(10.97)$ \\
Mean $(S D)$ &
\end{tabular}




\begin{tabular}{lc} 
Sex & \\
Male & $27(42)$ \\
Female & $37(58)$ \\
Years of experience & \\
1-9 years & $52(81)$ \\
$10-19$ years & $3(5)$ \\
$20-28$ years & $4(6)$ \\
29-39 years & $5(8)$ \\
Year of study & \\
First year & $5(8)$ \\
Second year & $8(12)$ \\
Third year & $11(17)$ \\
Fourth year & $4(6)$ \\
Five year & $10(16)$ \\
Several years & $23(41)$ \\
Disciplinary field & \\
Specialist health topic & $61(63)$ \\
Human and social sciences & $22(23)$ \\
Research methodologies & $9(9)$ \\
Management & $4(4)$ \\
Communication skills & $1(1)$ \\
\hline
\end{tabular}

The participants taught 97 different courses in the Health Sciences domain. Among the courses taught, a majority concerned specialist health topics (63\%). The data shows that the teachers in our sample were not specialised in the teaching of language (oral or written skills).

\section{Survey instrument}

The data were obtained through a three-part questionnaire that was specially constructed for the present study. The three sections were:

- Practices for teaching writing: teachers had to indicate how often they implemented specific pedagogical actions to help their students produce texts in their courses. This section of the questionnaire comprised 12 items that illustrated these pedagogical actions (see Table 2).

- Writing assessment practices: six items probed the criteria used by teachers to assess their students' written production (see Table 3).

- Text genre: the purpose of this section was to identify all the types of texts that the teachers asked their students to produce in their courses. The teachers had to 1) indicate how often they asked students to write each text genre from a predefined list 
of genres, and 2) list any other text genres they requested. These sections of the questionnaire will not be presented in the present paper.

To indicate the frequency of each item (see Tables 2 and 3), the participants were asked to choose one option amongst never, almost never, a few times, sometimes, frequently, very frequently, and always.

\section{Table 2. Items on the questionnaire: practices for teaching writing.}

When you ask students to produce a written text, what advice do you give them?

\begin{tabular}{ll}
\hline Item $\mathrm{n}^{\circ}$ & Sentence \\
\hline Q2 & $\begin{array}{l}\text { In the case of an essay, I say to them that the written text } \\
\text { must contain a critical personal analysis. } \\
\text { In the case of a research project, I say to them that the } \\
\text { written text must be founded on strong arguments and } \\
\text { theoretical bases. }\end{array}$ \\
Q3 & $\begin{array}{l}\text { I advise them to use the grammar rules in a convenient } \\
\text { manner. }\end{array}$ \\
Q4 & $\begin{array}{l}\text { I recommend that they write the introduction of a text at the } \\
\text { end of the writing activity. }\end{array}$ \\
Q5 & $\begin{array}{l}\text { I advise them to use the norms for producing scientific texts } \\
\text { with regard to our disciplinary context. }\end{array}$ \\
Q6 & $\begin{array}{l}\text { I explain genre characteristics (for example, to know that it is } \\
\text { expected to produce a critical point of view for a synthesis). }\end{array}$ \\
Q7 & $\begin{array}{l}\text { I recommend that they respect linguistic norms (spelling, } \\
\text { punctuation, use of upper- and lower-case letters). }\end{array}$ \\
Q8 & $\begin{array}{l}\text { I communicate to them how many pages they have to write. } \\
\text { I recommend that they make a plan or draft before they start } \\
\text { writing. }\end{array}$ \\
Q10 & $\begin{array}{l}\text { I advise them to reread their text before submitting it to their } \\
\text { teacher. }\end{array}$ \\
I propose that they construct the text progressively by \\
making corrections in a successive manner.
\end{tabular}

Table 3. Items on the questionnaire: practices for assessing writing

When you ask students to produce a written text, what criteria do you take into account to assess it?

\begin{tabular}{ll}
\hline Item $\mathrm{n}^{\circ}$ & Sentence \\
\hline Q13 & $\begin{array}{l}\text { The critical thinking and distance learning skills of the } \\
\text { students. }\end{array}$ \\
\hline
\end{tabular}




\begin{tabular}{ll}
\hline Q14 & Clarity of ideas, coherence and logical flow of ideas. \\
Q15 & $\begin{array}{l}\text { The mastery of theoretical and disciplinary knowledge } \\
\text { provided in the course. }\end{array}$ \\
Q16 & $\begin{array}{l}\text { The students' motivation for making the text. } \\
\text { Q17 }\end{array}$ \\
$\begin{array}{l}\text { Respecting norms for producing scientific texts with regard } \\
\text { to our disciplinary domain. } \\
\text { The use of grammar and spelling rules (punctuation, lexical } \\
\text { choices, writing style, fluency). }\end{array}$ \\
\hline
\end{tabular}

\section{Data analysis}

We ran cluster analyses to identity the teacher profiles by including the items in the questionnaire related to the teaching and assessment of writing as variables. We then used the Minimum variance method (Ward, 1963) to find the similarities between the participants whilst the differences between the profiles were established (we used an indicator named the squared Euclidean distance similarity measure). Next, we conducted a comprehensive analysis of categories found based on a graphic representation of the clustering of the items resulting from the Ward's method. Finally, we made a new analysis by using the k-means clustering method to verify the suitability of the initial cluster solution. This process was completed using a one-way analysis of variance (ANOVA) followed by a posthoc test that allowed a more precise comparison of the clusters ranged by pairs.

In addition to cluster analysis, we performed a Kruskal-Wallis $\mathrm{H}$-test to determine whether teacher profiles differed according to the variable we considered in this study, the age of participants.

\section{Results}

Using Ward's (1963) method allowed us to obtain a visual representation of the clustering of the items, which revealed three clusters. After careful inspection, we concluded that these three clusters made sense concerning the categories of teaching approaches we mentioned (see Introduction). The results of the cluster analysis are presented in Table 4.

Cluster 1 , which included the majority of the participants $(n=46)$, was characterised by the highest scores on items related to teaching linguistic norms $(Q 3, Q 7)$ and the constraints 
relative to the structure $(\mathrm{Q}, \mathrm{Q} 6)$ and organisation $(\mathrm{Q} 3, \mathrm{Q} 4)$ of written texts. These teachers scored the highest on items related to the teaching of writing methods, such as counselling students to review (Q10) or re-read (Q11) their texts. Two items probing assessment practices contributed to this profile, emphasising the importance of assessing student spelling abilities (Q18) and motivation (Q16). Taken together, the majority of items characterising Cluster 1 concerned teaching practices, with only a few probing assessment practices. This group of participants, therefore, seemed to focus on communicating the norms and constraints of writing, along with some of the strategies students can use to check that they have respected these norms. We named this profile transmitting, which means transmitting written production norms and methods for writing.

Cluster 2, which contained the fewest participants $(n=5)$, was more focused on items related to writing assessment, whether the criteria were based on linguistic aspects (Q5), disciplinary norms (Q17), students' theoretical knowledge (Q15), text organisation (Q12, Q14) or student reflexive abilities (Q13). One particular feature of this typology is that it considered disciplinary norms in relation to both teaching and assessment practices. Also, these participants scored the highest on teaching practices that emphasised the importance of exhibiting reflexive skills through written texts (Q1, Q2). Participants in this cluster clearly took account of the context in which the writing was to take place, the disciplinary norms and the epistemic function of writing. Cluster 2 revealed a teacher profile that emphasised the assessment of writing practices, which is why we named this profile assessing, which means assessing academic writing in context.

The teachers in Cluster $3(n=13)$ scored the lowest on all of the items. Their mean scores were particularly low on questions related to writers' knowledge and thinking qualities (Q1, Q2), as well as on items concerning teaching practices, such as giving advice on how to write, i.e., make a plan, etc. (Q4 and Q8). These participants would not teach or assess the written productions of their students according to a defined approach, or would simply not adhere to the different characteristics described in the questionnaire. We named this profile no adherence, which means no adherence to specific teaching and assessment approaches. 
Results of the post-hoc test (Table 4) provide a more detailed view of the differences between the profiles. The no adherence profile mainly differed from the other profiles on items related to teaching practices: encouraging reflexivity practices through writing (Q1, Q2); transmitting disciplinary norms (Q5); considering the number of pages to produce while planning (Q8); and communicating the structure a written text should have (Q12). It also differed significantly from the other two profiles on three assessment items: text coherence, theoretical knowledge and acquisition of disciplinary norms.

Table 4. Cluster analysis results.

\begin{tabular}{|c|c|c|c|c|c|c|}
\hline & $\begin{array}{c}\text { Cluster } \\
1 \\
(n=46) \\
\end{array}$ & $\begin{array}{c}\text { Cluster } \\
2 \\
(n=5) \\
\end{array}$ & $\begin{array}{c}\text { Cluster } \\
3 \\
(n=13)\end{array}$ & $\begin{array}{c}\mathrm{F} \\
(N=64)\end{array}$ & $p$ & $\begin{array}{l}\text { Post-hoc } \\
\text { test }\end{array}$ \\
\hline \multicolumn{7}{|l|}{ Teaching items } \\
\hline $\begin{array}{l}\text { Q1 Critical } \\
\text { analysis }\end{array}$ & 5,61 & 6 & 3,38 & 25,59 & 0.00 & $1>3^{\star *} ; 2>3^{\star *}$ \\
\hline $\begin{array}{l}\text { Q2 Arguments } \\
\text { and theoretical } \\
\text { bases }\end{array}$ & 5,57 & 6 & 3,31 & 18,85 & 0.00 & $1>3^{* *} ; 2>3^{* *}$ \\
\hline $\begin{array}{l}\text { Q3 Grammar } \\
\text { rules }\end{array}$ & 5,33 & 3,6 & 4,08 & 8,82 & 0.00 & $1>2^{*} ; 1>3^{* *}$ \\
\hline Q4 Introduction & 5,15 & 3,8 & 3,31 & 12,33 & 0.00 & $1>3^{* *}$ \\
\hline $\begin{array}{l}\text { Q5 Scientific } \\
\text { norms }\end{array}$ & 5,78 & 6 & 3,92 & 39,11 & 0.00 & $1>3^{\star \star} ; 2>3^{\star *}$ \\
\hline $\begin{array}{l}\text { Q6 Genre } \\
\text { characteristics }\end{array}$ & 5,52 & 4,8 & 4 & 20,31 & 0.00 & $1>3^{* *}$ \\
\hline $\begin{array}{l}\text { Q7 Linguistic } \\
\text { norms }\end{array}$ & 5,76 & 4,4 & 4,69 & 11,98 & 0.00 & $1>2^{*} ; 1>3^{\star *}$ \\
\hline $\begin{array}{l}\text { Q8 number of } \\
\text { pages }\end{array}$ & 5,24 & 5 & 3 & 17,64 & 0.00 & $1>3^{\star *} ; 2>3^{\star *}$ \\
\hline Q9 Plan of text & 5 & 1,8 & 3,54 & 33,77 & 0.00 & $\begin{array}{c}1>2^{\star \star} ; 2<3^{* *} \\
1>3^{* \star}\end{array}$ \\
\hline Q10 Rereading & 5,72 & 1,8 & 4,46 & 59,73 & 0.00 & $\begin{array}{c}1>2^{* *} ; 2<3^{*} ; \\
1>3^{* *}\end{array}$ \\
\hline $\begin{array}{l}\text { Q11 } \\
\text { Constructing } \\
\text { progressively }\end{array}$ & 5,04 & 4 & 3,15 & 15,33 & 0.00 & $1>3^{* *}$ \\
\hline $\begin{array}{l}\text { Q12 The parts of } \\
\text { the text }\end{array}$ & 5,65 & 5,8 & 3,54 & 33,77 & 0.00 & $1>3^{* *}$ \\
\hline
\end{tabular}

Assessing items

$$
5,67 \quad 5,8 \quad 4,85 \quad 6,91 \quad 0.02 \quad 1>3^{\star *} ; 1>3^{*}
$$




\section{Q13 Critical}

thinking

$\begin{array}{lcccccc}\text { Q14 Coherence } & 5,83 & 6 & 4,77 & 13,69 & 0.00 & 1>3^{* *} ; 2<3^{* *} \\ \begin{array}{l}\text { Q15Theoretical } \\ \text { knowledge }\end{array} & 5,8 & 6,2 & 4,85 & 11,29 & 0.00 & 1>3^{* *} ; 2<3^{* *} \\ \begin{array}{l}\text { Q16 Student } \\ \text { motivation }\end{array} & 5,63 & 5 & 4,77 & 5,46 & 0.07 & 1>3^{*}\end{array}$

Q17 Academic norms

5,59

5,8

4

13,29

$0.001>3^{* *} ; 2<3^{* *}$

Q18 Linguistic

${ }^{* *} p \leq .01 ;{ }^{*} p \leq .05$

$5,72 \quad 5,6 \quad 4,54 \quad 13,62 \quad 0.00 \quad 1>3^{* *} ; 2<3^{*}$

The transmitting profile scored higher than the assessing and no adherence profiles for the consideration of linguistic aspects for both teaching (Q3, Q7) and assessment (Q18) practices. Cluster 1 differed significantly from Cluster 3 solely on specific items, such as teaching practices where the characteristics of the text genre to be produced were explained to students (Q6) and they were advised to reread their texts (Q11). Finally, teachers with the transmitting profile were significantly more focused than those with the no adherence profile on assessing student motivation to write (Q16) and their spelling abilities (Q7).

Finally, the three profiles differed significantly on two specific items concerning teaching practices: recommending that their students plan their text before writing (Q9); and rereading their texts before handing them in (Q10). On these two items, Cluster 1 scored significantly higher than the other two groups of teachers.

\section{Differences between the teacher profiles}

A one-way ANOVA revealed a significant difference between the teacher profiles relating to their age $(X 2(2, N=64)=6.80, p=0.03)$. Teachers with the assessing profile were significantly younger than those with the no adherence profile $(p=0.01)$. In addition, the differences in age between the transmitting and no adherence profiles tended toward significance $(p=0.06)$. In contrast, no differences between the three profiles were found relative to the various years of experience. 


\section{Discussion}

The main aim of the present research was to characterise teacher profiles according to their teaching and assessment practices. We found three very different profiles, indicating that teaching approaches of teachers vary in the extent to which they integrate the epistemic role of writing in their self-reported practices.

The first profile corresponded to teaching practices based on the transmission of knowledge in specific linguistic and disciplinary domains. Teachers with this profile seemed to espouse the traditional conceptions of teaching focused on the teacher figure and the acquisition of knowledge. Findings on teaching approaches in higher education (Gow and Kember, 1993; Trigwell and Prosser, 1996; Eley, 2006) consistently show that some teachers view teaching above all as a means of communicating the ideas and knowledge that students need to learn in order to succeed. Under this approach, academic writing corresponds to mastering a set of norms, such as grammar and syntax, as well as other norms relating to the disciplinary content students learn.

The second profile (assessing) corresponded to a very different view of education and assessment practices, with an emphasis on the cultural characteristics of the disciplinary field in which the students produced their texts. Teachers belonging to this group acknowledged the need to encourage their students to think about where and why they write. In this sense, they gave priority to learning and adhering to disciplinary norms, in addition to practising highlevel reflective thinking skills through writing. This second profile appears to be related to a teaching approach, supported by evidence in the scientific literature (Gow and Kember, 1993), that focuses on student processes of knowledge construction.

One particular feature of this second profile is that the cognitive function of writing relates to assessment practices, rather than teaching practices. This means that, as in the case of our sample, teaching practices tending to encourage or train students to think reflectively through writing seem relegated to a secondary position. This finding is consistent with Escorcia (2015) in that some teachers emphasised the importance of the epistemic role of writing when they 
described their assessment criteria, but not when they described the advice they gave to their students.

The third (no adherence) profile is particularly interesting, as this group of teachers did not seem to be concerned with either teaching or assessing writing. Studies of the teaching practices of Colombian university teachers (Grijalva, 1999; González and Vega, 2010; López, 2010) have shown that some teachers assume that their students already know how to write, managing all the norms and skills they need to be efficient in this domain. We can surmise that for the third profile teachers, the mission of higher education institutions is not to make up for the deficiencies of secondary school, but to train experts in a given discipline, ensuring that they master specific scientific and technical knowledge. However, in order to confirm this hypothesis, it would seem necessary to know these teachers' perceptions with regard to teaching academic writing compared with the importance that they ascribe to other aspects of teaching and learning in higher education.

These three profiles show some coherence with the findings of Graham et al. (2002). Our first profile is close to the good writing profile identified by Graham et al. (2002), in that it gives priority to learning the norms of writing (mainly linguistic rules) and to judging in what ways the pupils respect these norms. This profile is also similar to a category of practices for teaching writing that, according to Lea and Street (1998), gives importance to language skills. Our second profile is quite similar to the explicit and direct instruction profile revealed by Graham et al. (2002), given that in both cases the cognitive dimension is considered essential. We observed, however, that our second profile takes into consideration a sociocultural perspective of writing that is not emphasised in the explicit and direct instruction profile identified by Graham et al. (2002). Consequently, our second profile seems to correspond more closely with a category of teaching writing that, following Lea and Street (1998), considers the discursive norms and sociocultural traits that influence the writing activities of students and teachers in higher education.

In relation to the interactions between teacher profiles and individual's age, we found that teacher age was significantly related to the profiles, with the oldest participants exhibiting a no adherence profile and the youngest revealing an assessing profile. This finding is consistent 
with that of Norton et al. (2005). We can compare the influence of an individual's age with that of their years of teaching experience. Some studies demonstrating the influence of this latter variable (Gobat and Berger, 2018) have argued that more experienced teachers declare a more traditional vision of teaching for either of the following reasons: a) generational effects, or b) the tendency of older persons to be more closely aligned with traditional values. Based on a generational effects hypothesis, we might suggest that the oldest teachers in our study have been less affected by changes in education practices in Colombian universities, which have only recently started giving university teachers a greater role in the learning and overall success of their students.

The third profile illustrates a more traditional vision of teaching at the post-secondary level, where teachers seem not to be actively involved in university student learning processes. Conversely, teachers with the second profile were the youngest, probably indicating that their teaching and assessment practices have been more influenced by the aforementioned contemporary questions about practices in higher education in this country.

Our findings also show coherence with Feixas' (2010) results, which revealed a correspondence between a university teacher's age and their teaching profile. The oldest tended to focus on the knowledge they communicated, implementing, above all, an expositive education style. In contrast, the youngest teachers were more centred on interactions and knowledge exchanges with and between learners. Feixas (2010) argued that this latter group had probably experienced professional development influenced by education theories and pedagogic models that focused more on students.

\section{Conclusion}

The present study aimed to typify the profiles of university teachers with regard to their teaching and assessment of academic writing, and to identify to what extent the teacher profiles varied as a function of their age. We sought to understand whether teachers promoted the epistemic function of writing. 
We observed that the majority of teachers corresponded to profiles unlikely to consider an active role for teachers in the promotion of student learning of academic writing. Only the youngest teachers considered the cognitive dimension of writing and the sociocultural variables that contributed to the mastery of academic writing. The profiles we found confirm the traditional categorisation of teaching approaches in higher education as constituted by two poles, teacher-focused and student-focused.

Our research has some limitations. The instrument used was not exhaustive in that it certainly does not consider all of the diversity of practices for teaching writing. For example, no item questioned factors around identity or how students and teachers experience the appropriation of disciplinary contextual norms. This factor illustrates a category that, according to Lea and Street (1998), plays an essential role in the practice of academic writing. Another limitation is that the profiles identified are only valid for teachers in the Health domain. If we are taking a sociocultural approach to writing, it would seem necessary to test these categories against teachers from other disciplines.

The present research was based on an exploratory and qualitative method that we implemented previously (Escorcia, 2015). This new quantitative stage of the research could facilitate a comparative approach that would seem to be necessary if we are to understand the variations among university teacher approaches related to academic writing in different disciplinary and cultural contexts.

\section{Acknowledgements}

We thank Action-Research-Training's programme of the School of Teaching Training (ESPé) of the University of Poitiers, and the Research and Projects department (DPI) of the Universidad del Norte (Colombia), for having contributed to the partial funding of the present work.

\section{References}


Arévalo, L. F., Campo, O. M., Chois, P., Escobar, R. A., Ordóñez, N. M., Ortega, J. O., Sandoval, C. E. and Valencia, A. M. (2008) Lineamientos generales para los cursos de lectura y escritura'. Popayán: Universidad del Cauca. (Accessed: 12 June 2019).

Escorcia, D. (2012). 'Conceptions de l'écriture à l'université: analyse des représentations d'enseignants français et colombiens'. Recherches en didactiques- Les Cahiers Théodile, 12, pp. 123-141.

Escorcia, D. (2015). 'Teaching and assessing writing skills at university level: A comparison of practices in French and Colombian universities'. Educational Research, 57(03), pp. 254-271. Available at: https://doi.org/10.1080/00131881.2015.1056641 (Accessed 2 July 2019).

Escorcia, D., Moreno, M., Campo, K., and Palacios, J. (2014). ‘Enseñanza y evaluación de la escritura en la universidad: análisis de prácticas declaradas de docentes franceses y colombianos'. Zona Próxima, 0(20). Available at:

http://rcientificas.uninorte.edu.co/index.php/zona/article/view/6007 (Accessed 12 July 2019).

Campo, K., Escorcia, D., Moreno, M., and Palacio, J. (2016). 'Metacognición, escritura y rendimiento académico en universitarios de Colombia y Francia'. Avances en psicología latinoamericana. 34(2), pp. 233-252.

Bereiter, C. (1980) 'Development in writing', in Gregg, L. M. and Steinberg, E. R. (eds.) Cognitive processes in writing. Hillsdale, NJ: Erlbaum, pp. 73-96.

Carlino, P. (2005) Escribir, leer y aprender en la universidad: una introducción a la alfabetización. Edición reimpresa. Buenos Aires: Fondo de Cultura Económica.

Castelló, M. and Mateos, M. (2015) 'Las representaciones de profesores y estudiantes sobre la escritura académica en las universidades españolas', Cultura y Educación 27(3), pp. 489-500. 
Cadena, S., Narvaez, E. and Chacon, M. (2007) ‘Comprensión de textos escritos académicos y tareas escritas en las asignaturas del área profesional: concepciones de maestros universitarios', Lenguaje, 35, pp. 81-118.

Delcambre, I., Donahue, T. and Lahanier-Reuter, D. (2012) 'Ruptures et continuités dans l'écriture à l'université'. Scripta, 13(24), pp. 227-244 Available at: http://periodicos.pucminas.br/index.php/scripta/article/view/4405. (Accessed: 12 July 2019).

Eley, M. G. (2006) 'Teachers' conceptions of teaching, and the making of specific decisions in planning to teach', Higher Education, 51(2), pp. 191-214. Available at: https://doi.org/10.1007/s10734-004-6382-9 (Accessed: 12 December 2019).

Feixas, M. (2010). Enfoques y concepciones docentes en la universidad. Relieve, 16(2), pp. 1-27. http://www.uv.es/RELIEVE/v16n2/RELIEVEv16n2 2.htm. (Accessed: 2 July 2019).

Gobat, E. and Berger, J. L. (2018) 'Les croyances pédagogiques et identitaires des enseignants de la formation professionnelle: le rôle de l'expérience d'enseignement et de la formation pédagogique'. Canadian Journal of Education/Revue Canadienne de l'éducation, 41(2), pp. 441-471.

González, B. and Vega, V. (2010) Prácticas de Lectura y Escritura en la universidad. El caso de cinco asignaturas de la Universidad Sergio Arboleda. Bogotá: Fondo de publicaciones. Universidad Sergio Arboleda.

Gow, L. and Kember, D. (1993) 'Conceptions of teaching and their relationship to student learning', British Journal of Educational Psychology, 63(1), pp. 20-23.

Graham, S., Harris, K. R., MacArthur, C. A. and Fink, B. (2002) 'Primary grade teachers' theoretical orientations concerning writing instruction: construct validation and a 
nationwide survey', Contemporary Educational Psychology, 27, pp. 147-166. Available at: http://dx.doi.org/10.1006/ceps.2001.1085 (Accessed: 5 July 2019).

Grijalva, A. (1999) 'Reflexiones sobre pedagogía universitaria'. Bull. Instituto Francés de Estudios Andinos 28(3), pp. 451-460. Available

at: https://www.redalyc.org/pdf/126/12628310.pdf (Accessed: 5 July 2019).

Hayes, J. R. (2012) 'Modeling and remodeling writing', Written Communication, 29(3), pp. 369-388. Available at: https://doi.org/10.1177/0741088312451260 (Accessed: 10 June 2019).

Kellogg, R. T. and Raulerson, B. (2007) 'Improving the writing skills of college students', Psychonomic Bulletin and Review, 14(2), pp. 237-242. Available at: https://doi.org/10.3758/BF03194058 (Accessed: 10 June 2019).

Lea, M. R., and Street, B. V. (1998) 'Student writing in higher education: an academic literacies approach', Studies in Higher Education, 23(2), pp. 157-172. Available at: https://doi.org/10.1080/03075079812331380364 (Accessed: 5 July 2019 ).

Le Huu Nghia, T. (2017) 'What hinders teachers from translating their beliefs into teaching behaviors: the case of teaching generic skills in Vietnamese universities', Teaching and Teacher Education, 64, pp. 105-114. Available at: https://doi.org/10.1016/j.tate.2017.02.003 (Accessed: 5 June 2019 ).

López, G. (2010) La pedagogía crítica en el lesalc/Unesco y La Universidad Colombiana en el marco de la revolución educativa entre el 2005-2010. Available at: http://www.eumed.net/libros-gratis/2011a/910/indice.htm (Accessed: 10 December 2019).

Norton, L., Richardson, J. T. E., Hartley, J., Newstead, S. and Mayes, J. (2005) 'Teachers' beliefs and intentions concerning teaching in higher education', Higher Education, 50(4), pp. 537-571. 
Organisation for Economic Cooperation and Development. (1996) The knowledge-based economy, OECD, (OECD/GD (96)102), pp. 1-46.

Pérez, M., Barrios, M. and Zuluaga, Z (2010) ¿Cómo se enseña el lenguaje en Colombia? Grupo de investigación pedagogías de la lectura y la escritura. Bogotá: Pontificia Universidad Javeriana.

Reuter, Y. (1996) Enseigner et apprendre à écrire: construire une didactique de l'écriture. Paris: ESF éditeur.

Trigwell, K. and Prosser, M. (1996) 'Congruence between intention and strategy in university science teachers' approaches to teaching', Higher Education, 32(1), pp. 77-87. Available at: https://doi.org/10.1007/BF00139219 (Accessed: 12 December 2019).

Vargas, A. (2007) Escribir en la universidad. Reflexiones y estrategias sobre el proceso de composición escrita de textos académicos, Lenguaje, 33, pp. 97-125.

Ward, J. (1963) 'Hierarchical grouping to optimize an objective function', Journal of the American Statistical Association, 58, pp. 236-244.

\section{Author details}

Dyanne Escorcia is assistant professor at Université de Poitiers, France. She teaches subjects about learning theories and pedagogical practices, the writing learning processes, and teaching and learning in the university context. Her research focuses on the cognitive and metacognitive aspects of writing and the teaching practices relative to writing in postsecondary education.

Mayilin Moreno is professor of the psychology department of the Universidad del Norte de Barranquilla, Colombia. In 2014, she received a PhD in psychology from Toulouse Jean Jaures University. She currently researches in the line of psychology of cognitive processes and early language development. 